The

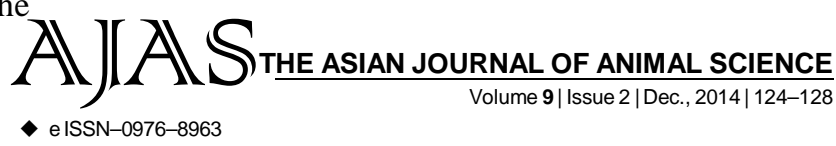

DOI : 10.15740/HAS/TAJAS/9.2/124-128 Visit us | www.researchjournal.co.in $S^{2}$

RESEARCH ARTICLE........

\title{
Fish diversity and conservation of fishery resources of the river Pilasalunki, Phulbani district
}

\author{
D. SATAPATHY AND S.K. MISRA
}

Author for Corresponding -

\section{SATAPATHY}

College of Fisheries (O.U.A.T.), BERHAMPUR (ODISHA) INDIA Email: dircof2012@gmail.com

See end of the article for

Coopted authors'
ABSTRACT...... The study of fish diversity of the river Pilasalunki situated in Phulbani distict, Odisha was attempted during 2012. A total of 23 fish species belonging to 9 families were recorded. Out of the recorded species, 35 per cent are enlisted as vulnerable, 52 per cent as lower risk near threatened category. Maximum number of fish species were collected from slow flow site $(31.6 \%)$ followed by silty sand beds (17.6\%), deep water zone (15.8\%), gravel habitat $(15.8 \%)$, fast flow zone $(10.5 \%)$ and least in shallow water zone. Shannon diversity index (H') fluctuated from 0.29 to 0.93 , Simpson dominance index ranged from 0.14 to 0.52 and Margalef richness fluctuated from 1.38 to 9.65. Bray Curtis cluster analysis recorded 100 per cent similarities within Wallago attu, Labeo dyochilus and Nemacheilus botia (sub cluster-I), Puntius sarana, P. Sophore, and Mystus cavasius (sub cluster-II), Glosogobius giuris and Mastacembalus armatus (sub cluster-III). Correspondence analysis indicated Nemacheilus botia, Labeo dyochilus, Heteropneustes fossilis, Wallago attu, Cirrhinus reba, Glosogobius giuris, Mastacembalus armatus and Mystus cavasius, Channa gachua, Puntius sophore and Puntius sarana congregated distantly from origin suggesting their stock enhancement through conservation measures.

KEY WORDS...... Fish diversity, Shannon's diversity index, Bray Curtis similarity

HOW TO CITE THIS ARTICLE - Satapathy, D. and Misra, S.K. (2014). Fish diversity and conservation of fishery resources of the river Pilasalunki, Phulbani district. Asian J. Animal Sci., 9(2) : 124-128.

ARTICLE CHRONICLE - Received : 04.06.2014; Revised : 21.10.2014; Accepted : 06.11.2014 